\title{
Preclinical Study on the Hepatoprotective Effect of Pollen Extract of Pinus brutia Ten. (Red Pine) in Mice and Phenolic Acid Analysis
}

\author{
Pinus brutia Ten. (Kızılçam) Polen Ekstresinin Karaciğer Koruyucu Etkisinin \\ Preklinik Olarak Araştırılması ve Fenolik Asit Analizleri
}

\author{
(D) Hasya Nazlı GÖK¹, (D) Hina GÜL², (D) Muhammad GÜLFRAZ², (D) Muhammad Javaid ASAD², (D) Nilgün ÖZTÜRK3 , (D) Fuat ȘANAL4 \\ (D) İlkay Erdoğan ORHAN* \\ ${ }^{1}$ Gazi University Faculty of Pharmacy, Department of Pharmacognosy, Ankara, Turkey \\ 2PMAS Arid Agriculture University, Institute of Biochemistry and Biotechnology, Rawalpindi, Pakistan \\ ${ }^{3}$ Anadolu University Faculty of Pharmacy, Department of Pharmacognosy, Eskișehir, Turkey \\ ${ }^{4}$ General Directorate of Forestry, Chairmanship of Inspection Committee, Ankara, Turkey
}

\begin{abstract}
Objectives: Many agents, including those from herbal sources, have been sought as preventives or cures for hepatotoxicity. The pollen of Pinus brutia Ten., known as red pine (Pinaceae), is used against liver diseases in Anatolian folk medicine.

Materials and Methods: In the current study, pollen ethanol extract of $P$. brutia was investigated for its possible hepatoprotective activity using a mouse model of $\mathrm{CCl}_{4}$-induced hepatotoxicity. Swiss albino mice were divided into five groups, and extract-treated groups were compared with a silymarin-treated group as the reference. The extract was tested at 100,200 , and $300 \mathrm{mg} / \mathrm{kg}$ (b.w.). Phenolic acids were analyzed using highperformance column chromatography (HPLC) in the extracts as pollens are usually known to be rich in phenolics.

Results: Our data revealed that the extract displayed the best hepatoprotection at a dose of $100 \mathrm{mg} / \mathrm{kg}$ when compared with silymarin (Legalon ${ }^{\circledR}$ ), the reference drug. HPLC analysis indicated presence of protocatechuic acid $(0.176 \mathrm{mg} / \mathrm{g}$ extract), p-hydroxybenzoic acid (0.001 $\mathrm{mg} / \mathrm{g}$ extract), vanillic acid (VA) $(0.537 \mathrm{mg} / \mathrm{g}$ extract), syringic acid $(0.050 \mathrm{mg} / \mathrm{g}$ extract), and $\mathrm{tr}$-cinnamic acid $(0.310 \mathrm{mg} / \mathrm{g}$ extract), while the major phenolic acid was VA. Conclusion: The outcomes of this study allow us to conclude that red pine pollen extract can serve as a promising hepatoprotective agent. Among the phenolic acids analyzed in the pollen extract, vanillic acid as the major one besides some other phenolic acids detected seems to be responsible for its remarkable hepatoprotective effect.
\end{abstract}

Key words: Pinus brutia, red pine, pollen, hepatoprotective activity, HPLC

ÖZ

Amaç: Hepatotoksisiteyi önlemek veya iyileştirmek için bitkisel kaynaklar dahil olmak üzere birçok bileşik araştırılmaktadır. Kızılçam olarak bilinen Pinus brutia Ten. bitkisinin polenleri Anadolu'da halk arasında karaciğer rahatsızlıklarında kullanılmaktadır.

Gereç ve Yöntemler: Bu çalıșmada, $P$. brutia polen ekstresinin farelerde $\mathrm{CCl}$, ile indüklenen hepatotoksisite modeli üzerindeki muhtemel hepatoprotektif etkisi araştırılmıştır. Swiss albino fareler 5 gruba ayrılmış ve ekstrakt uygulanan gruplar referans olarak silimarin (Legalon $\left.{ }^{\circledR}\right)$ kullanılan grup ile karşılaştırılmıştır. Ekstreler 100, 200 ve 300 mg/kg (v.a.) konsantrasyonlarında çalışılmıştır. Polenlerin genellikle fenolik açıdan zengin olduğu bilindiğinden, ekstrede bulunan fenolik asitler yüksek performanslı sıvı kromatografisi (HPLC) kullanılarak analiz edilmiștir.

Bulgular: Sonuç olarak, ekstrenin referans ilaç olan silimarin (Legalon ${ }^{\circledR}$ ) ile karşılaştırıldığında, en etkin hepatoprotektif etkiyi 100 mg/kg'lik dozda gösterdiği belirlenmiştir. HPLC analizi ekstrede protokateşik asit $(0,176 \mathrm{mg} / \mathrm{g}$ ekstre), p-hidroksibenzoik asit $(0,001 \mathrm{mg} / \mathrm{g}$ ekstre), vanilik asit (VA) $(0,537 \mathrm{mg} / \mathrm{g}$ ekstre), siringik asit $(0,050 \mathrm{mg} / \mathrm{g}$ ekstre), ve tr-sinnamik asit $(0,310 \mathrm{mg} / \mathrm{g}$ ekstre) bulunduğunu, en yüksek miktardaki fenolik asidin ise VA olduğunu ortaya koymuştur.

Sonuç: Çalışmamız neticesinde, kızılçam polen ekstresinin umut verici bir hepatoprotektif ajan olarak kullanılabileceği sonucuna varılmıştır. Polen ekstresinde analiz edilen fenolik asitler arasında, majör olan vanilik asidin yanı sıra bazı diğer fenolik asitlerin ekstrenin gösterdiği hepatoprotektif etkiden sorumlu olduğu düşünülmektedir.

Anahtar kelimeler: Pinus brutia, kızılçam, polen, hepatoprotektif aktivite, HPLC 


\section{INTRODUCTION}

The liver is one of the most important organs that regulate metabolic functions, hormones, and defense mechanisms in the body. On the other hand, the liver is exposed to many threats, such as alcohol, viruses, and xenobiotics; hence, protection of the liver is essential to the maintenance of liver function.,2 The genus Pinus (Pinaceae) contains approximately 80 species with a worldwide distribution. ${ }^{3}$ In Turkey, Pinus contains seven species, Pinus pinaster Aiton, $P$. brutia Ten., $P$. halepensis Mill., $P$. pinea L., $P$. sylvestris L., $P$. nigra J.F.Arnold, and $P$. radiata D.Don. ${ }^{4} P$. brutia Ten. (red pine) is spread out over Eastern Mediterranean countries such as Turkey, Greece, and Cyprus; Black Sea countries such as Ukraine and Georgia; and the Caucasus countries. ${ }^{5}$ Different parts of $P$. brutia, such as the bark, resin, tar, and cones, are used to treat asthma, bronchitis, cancer, diabetes, diarrhea, pneumonia, and tuberculosis in Turkish folk medicine. ${ }^{6-9}$

Pollens from many kinds of plants have been used as food traditionally for many years, even since pre-historic times. ${ }^{10-16}$ Pine pollen, which is the male spores of Pinus, have been used to protect the liver, combat senility and fatigue, treat gastrointestinal dysfunction, improve sexual function, and increase cerebral-cardiac blood vessel function for many years. ${ }^{17,18}$ The relevant literature survey shows that most previous studies on $P$. brutia were conducted on its bark. On the other hand, $P$. brutia bark contains some phenolic compounds, such as 4-hydroxybenzoic acid, resveratrol, gentisic acid, vanillin, vanillic acid (VA), catechin hydrate, p-coumaric acid ( $p-C O U$ ), ferulic acid (FA), protocatechuic acid (proCA), gallic acid (GA), myricetin, naringenin, caffeic acid (CA), luteolin, and kaempferol. ${ }^{19}$ On the other hand, there have been a few studies on the phytochemistry and biological activity on the pollens of P. brutia. ${ }^{20-26}$

There have been several studies describing the hepatoprotective effect of various pollens, such as bee pollen and that of chestnut, canola, P. massoniana, Schisandra chinensis, etc. ${ }^{27-32}$ However, no reports on the hepatoprotective effect of pollen from $P$. brutia are available to date, although it is used against liver diseases around Muğla province in the Aegean region of Turkey (personal communication). Taking this information into account, we aimed to perform the present study in order to evaluate anecdotal claims of the hepatoprotective use of red pine pollen ethanol extract using carbon tetrachloride $\left(\mathrm{CCl}_{4}\right)$-induced liver damage in mice and to identify major phenolic acids in the extract using high-performance column chromatography (HPLC).

\section{MATERIALS AND METHODS}

\section{Experimental}

\section{Plant material}

The pollen of $P$. brutia trees was collected from the forest area belonging to the General Directorate of Forestry, Ministry of Agriculture and Forestry, in the vicinity of Antalya province, Turkey in June 2015.

\section{Preparation of the extract}

Air-dried pollens $(51.15 \mathrm{~g}$ ) of $P$. brutia were macerated with $800 \mathrm{~mL}$ ethanol (80\%) for $24 \mathrm{~h}$ twice at room temperature. The ethanol macerate was filtrated and evaporated to dryness in vacuo. The yield of the crude extract was $24.98 \%(\mathrm{w} / \mathrm{w})$.

\section{High-performance liquid chromatography analysis}

Chemicals used for HPLC (methanol and formic acid) analysis were of chromatographic grade (Sigma-Aldrich, St. Louis, MO, USA). Phenolic acid standards, e.g., GA, proCA, p-OHBA (4-hydroxybenzoic acid), VA, CA, chlorogenic acid, syringic acid (SA), p-COU, FA, o-coumaric acid, rosmarinic acid, and trans-cinnamic acid (tr-CIN) used in HPLC analysis were purchased from Sigma-Aldrich (St. Louis, MO, USA) or Merck ( $\mathrm{GmbH}$, Darmstadt, Germany). Analysis of phenolic acids in the extract was carried out with an Agilent 1.100 series autosampler system from Agilent, GL Sciences Inc. (Waldbronn, Germany) equipped with a system controller, a DAD detector ( $G$ 1315B, $280 \mathrm{~nm}$ ), and a quaternary LC pump (G1311A). The separation was carried out with a Zorbax Eclipse XDB-C18 column (150 mm, $4.6 \mathrm{~mm}$ i.d., and $5 \mu \mathrm{m}$ particle size) (Agilent, Waldbronn, Germany) with the column temperature set at $25^{\circ} \mathrm{C}$. Chromatographic separation was carried out using two solvent systems: A) methanol:water:formic acid (10:88:2, v/v/v) and B) methanol:water:formic acid (90:8:2, v/v/v), as reported elsewhere. ${ }^{33}$ The analyses were performed by using a linear gradient program. The conditions were $100 \%$ A from 0 to 15 $\min , 100 \%$ A from 15 to $20 \mathrm{~min}, 85 \%$ A from 20 to $30 \mathrm{~min}, 50 \%$ A from 30 to $35 \mathrm{~min} 0 \% \mathrm{~A}$ from 36 to $42 \mathrm{~min}$, and returned to $100 \% \mathrm{~A}$. The flow rate was $1 \mathrm{~mL} / \mathrm{min}$, and the injection volume was $10 \mu \mathrm{L}$. Signals were detected at $280 \mathrm{~nm}$. The extract was dissolved in a mixture of methanol and water (1:1, v/v) and injected into the HPLC.

Each compound was identified by its retention time and by spiking with the standards under the same conditions. The identities of phenolic acids were also confirmed with a photodiode array detector by comparison with the ultraviolet spectra of standards in the wavelength range of 220-320 nm. Each compound was quantified according to the peak area measurements, which were reported in calibration curves of the corresponding standards. Data are reported as means \pm standard deviations of three independent analyses.

\section{Animals}

Swiss albino mice of either sex (50 to $70 \mathrm{~g}$ ) were maintained under standard animal housing conditions fed with commercial mice chow and allowed water ad libitum. The experimental protocol was approved by an Institutional Ethic Committee constituted by PMAS Arid Agriculture University Rawalpindi for the animal study.

\section{Hepatoprotective activity}

Forty mice were divided into eight groups of five each $(n=5)$. Group 1: The control group received $0.5 \mathrm{~mL}$ of saline $(0.9 \%, \mathrm{v} / \mathrm{v})$ in water. Group 2: Animals of this group received $0.5 \mathrm{~mL}$ of olive oil ( $0.5 \%)$. Group 3: Animals of this group received ethanol $(0.2 \%, v / v)$. All of these animals received doses once per day for 
the entire period ( 7 days) by i.p. injection, respectively. Animals of group 4 were administrated i.p. with $\mathrm{CCl}_{4}$ dissolved in olive oil at a dose of $0.5 \mathrm{~mL} / \mathrm{kg} /$ day body weight. Animals of groups 4 to 8 were administrated i.p. with $\mathrm{CCl}_{4}$ dissolved in olive oil at a dose of $0.5 \mathrm{~mL} / \mathrm{kg} /$ day body weight (b.w.).

Animals of group 5 were fed with silymarin dissolved in ethanol at a dose of $50 \mathrm{mg} / \mathrm{kg} /$ day. Animals of group 6 were fed with the pollen ethanol extract at dose of $100 \mathrm{mg} / \mathrm{kg}$ once per day by gavage, while animals of group 7 and 8 were fed with the extract at doses of 200 and $300 \mathrm{mg} / \mathrm{kg}$, respectively, once per day by gavage. At the end of the experiments, all mice were sacrificed, serum was collected, the livers were removed, and washed with ice-cold physiological saline.

\section{Acute oral toxicity study}

An acute toxicity study was conducted for a selected suitable dose of plant extracts. ${ }^{34}$ Approximately 100 to $300 \mathrm{mg}$ of dried pollen extract was dissolved in $5 \mathrm{~mL}$ of ethanol, and $1 \mathrm{~mL}$ of each dose was given to animals by gavage.

\section{Biochemical analysis}

Organs were homogenized in $0.1 \mathrm{M}$ Tris $\mathrm{HCl}$ buffer $(\mathrm{pH} 7.4)$ to give a $10 \%$ homogenate. This homogenate was used for the estimation of triglycerides, high-density lipoprotein (HDL) cholesterol, and low-density lipoprotein (LDL) cholesterol by using commercial kits (Randox Laboratory) and the enzymatic method of Bierman. ${ }^{35}$ The enzymes alanine aminotransferase $(A L T)$, aspartate aminotransferase (AST), and alkaline phosphatase (ALP); total bilirubin; red blood cell count (RBC); white blood cell count (WBC); and platelet levels were estimated by using their respective diagnostic kits and an autoanalyzer (Merck). The body weights of animals were calculated by measuring the weight before and after treatment with the extract.

\section{Statistical analysis}

All values are expressed as mean \pm standard deviation. OneWay ANOVA was used to determine the consequences of different treatments by using the computer software GraphPad Prism 5.0.

\section{RESULTS AND DISCUSSION}

\section{HPLC analysis}

The pollen ethanol extract was analyzed by HPLC, which led to identification and quantification of the following phenolic acids: proCA $(0.176 \mathrm{mg} / \mathrm{g}$ extract), p-hydroxybenzoic acid $(0.001 \mathrm{mg} / \mathrm{g}$ extract), VA ( $0.537 \mathrm{mg} / \mathrm{g}$ extract), SA $(0.050 \mathrm{mg} / \mathrm{g}$ extract), and tr-CIN acid ( $0.310 \mathrm{mg} / \mathrm{g}$ extract). The major phenolic acid was found to be VA (Figure 1).

\section{Results of liver enzymes, lipid profiles, and blood cells}

When the effects of the extract on mouse lipid profiles were examined, the pollen extract was found to reduce triglycerides and total cholesterol levels significantly at the $100 \mathrm{mg} / \mathrm{kg}$ dose. Nevertheless, the extract also reduced the HDL cholesterol level (Table 1). Although the extract applied at the 200 and 300 $\mathrm{mg} / \mathrm{kg}$ doses decreased the triglyceride and cholesterol levels, the activities were lower than that of the $100 \mathrm{mg} / \mathrm{kg}$ extract. The extract at a dose of $100 \mathrm{mg} / \mathrm{kg}$ exhibited a greater reducing effect than that of silymarin.

Our data indicated that plasma levels of AST and ALT enzymes were notably elevated in rats treated with $\mathrm{CCl}_{4}$. The ALT, AST, ALP, and bilirubin levels were diminished drastically with extract at the $100 \mathrm{mg} / \mathrm{kg}, 200 \mathrm{mg} / \mathrm{kg}$, and $300 \mathrm{mg} / \mathrm{kg}$ doses (Table 2). The activity of the extract on these enzymes and proteins was higher than that of the reference drug, silymarin. Considering the pollen extract treatment on blood cells, the counts of reduced RBC and WBC was increased, so the extract presented a similar effect to that of silymarin (Table 3).

\section{Histopathologic findings}

Histopathologic data displayed that livers from the healthy mouse group showed normal hepatocyte structures. However, after administration of $\mathrm{CCl}_{4}$, complete loss of liver architecture was observed, whereas the damaging effects of $\mathrm{CCl}_{4}$ were reversed by treatment with the pollen extract (Figure 2). The recovery of tissue was significant when it was treated with the $300 \mathrm{mg} / \mathrm{kg}$ dose of the pollen extract, which indicated that tissue regeneration was dose-dependent (Figure $2 e$ ), while similar results were obtained when the hepatoprotective agent was used, i.e., silymarin (Figure $2 b$ ).
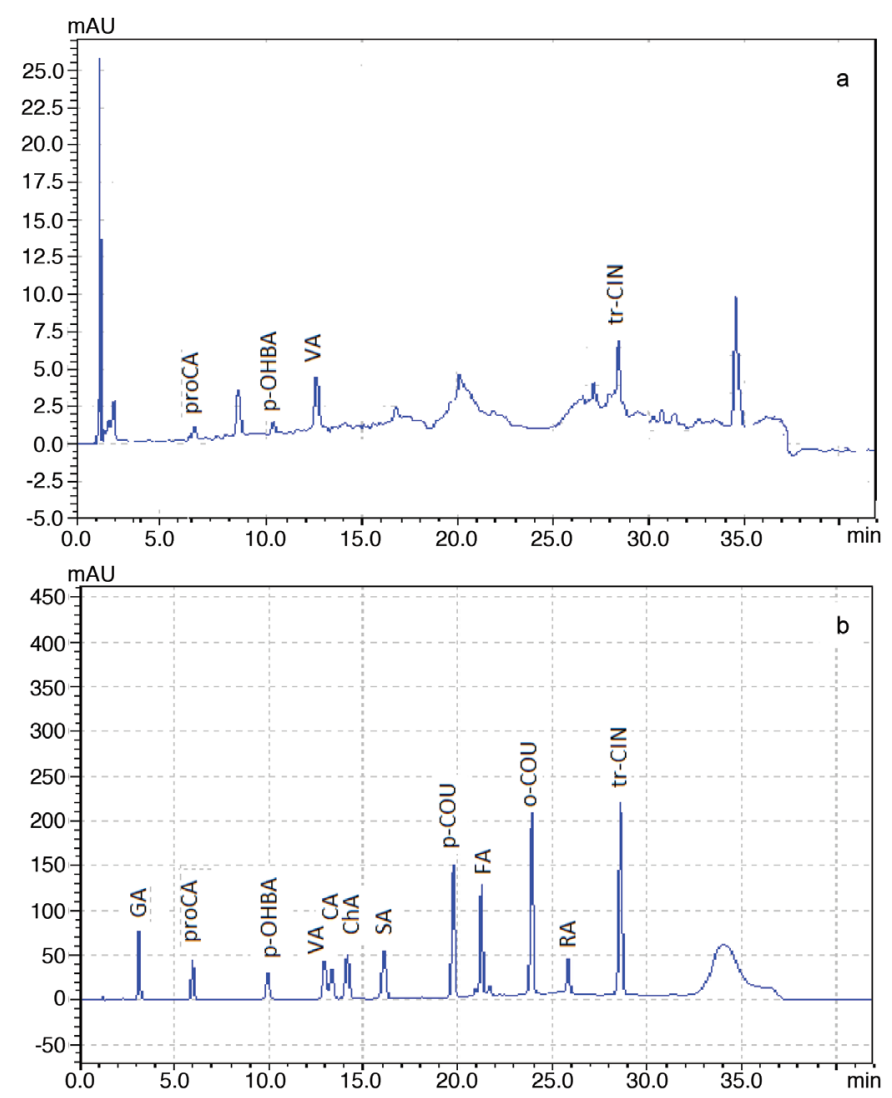

Figure 1. HPLC chromatograms of the pollen extract (a) and standard phenolic acids (b)

HPLC: High-performance column chromatography, GA: Gallic acid, proCA: Protocatechuic acid, VA: Vanillic acid, SA: Syringic acid, p-OHBA: 4-hydroxybenzoic acid, p-COU: P-coumaric acid, tr-CIN: Trans-cinnamic acid 
Liver damage induced by $\mathrm{CCl}_{4}$ in rats is one of the most preferable experimental models for the study of hepatoprotection. Several studies have been performed to determine the hepatoprotective or lipid-lowering effects of the various aforementioned pollen extracts as the liver is known to play the foremost role in lipid transformations. ${ }^{27-32}$ Pollen grains are the tiny male particles released from trees, weeds, and grasses. The main function of pollen grains is to fertilize other parts of plants. An early study on a flower pollen extract $(0.4 \mathrm{~mL} / 100 \mathrm{~g}$ b.w. $)$, in which the name of the extract was mentioned as cernitins, was described to possess a hepatoprotective effect on livers damaged by alcohol by reducing serum AST and ALT levels.

Another pollen extract from a flower, whose scientific or local name was not indicated, was reported to exert a

\section{Table 1. Effects of red pine pollen extract on the lipid profiles of mice}

\begin{tabular}{lllll} 
Group & Treatment & Triglycerides $(\mathrm{mg} / \mathrm{dL})$ & Cholesterol $(\mathrm{mg} / \mathrm{dL})$ & $\mathrm{HDL}(\mathrm{mg} / \mathrm{dL})$ \\
\hline 1 & Normal (vehicle) & $81.15 \pm 1.22$ & $65.38 \pm 2.34$ & $59.24 \pm 2.36$ \\
\hline 2 & Olive oil group & $75.27 \pm 2.51$ & $71.34 \pm 1.34$ & $45.43 \pm 1.23$ \\
\hline 3 & Ethanol group & $82.35 \pm 2.37^{*}$ & $66.24 \pm 2.14^{*}$ & $54.26 \pm 1.45^{*}$ \\
\hline 4 & $\mathrm{CCl}_{4}+$ olive oil & $142.35 \pm 2.37$ & $132.35 \pm 0.39$ & $112.35 \pm 1.34$ \\
\hline 5 & Silymarin + olive oil & $89.31 \pm 1.32$ & $74.12 \pm 1.25$ & $62.17 \pm 0.38$ \\
\hline 6 & Pollen extract at $100 \mathrm{mg} / \mathrm{kg}$ & $82.31 \pm 1.27^{*}$ & $59.23 \pm 2.14^{*}$ & $47.26 \pm 1.45^{*}$ \\
\hline 7 & Pollen extract at $200 \mathrm{mg} / \mathrm{kg}$ & $91.38 \pm 2.76$ & $88.34 \pm 1.32$ & $51.24 \pm 2.35$ \\
\hline 8 & Pollen extract at $300 \mathrm{mg} / \mathrm{kg}$ & $98.35 \pm 1.52$ & $89.65 \pm 0.57$ & $52.78 \pm 1.45$ \\
\hline
\end{tabular}

*Significant $(p<0.05)$ values vs. control/normal and expressed as mean $\pm S D, n=5$

$\mathrm{CCl}_{4}$ : Carbon tetrachloride, HDL: High-density lipoprotein, SD: Standard deviation

Table 2. Effects of red pine pollen extract on liver enzyme and proteins in mice

\begin{tabular}{llllll} 
Group & Treatment & ALT (U/L) & AST (U/L) & ALP (U/L) & Bilirubin (mg/dL) \\
\hline 1 & Normal (vehicle) & $81.15 \pm 1.21$ & $65.38 \pm 2.34$ & $59.24 \pm 2.36$ & $0.146 \pm 0.028$ \\
\hline 2 & Olive oil group & $75.27 \pm 1.51$ & $62.54 \pm 1.33$ & $45.43 \pm 1.25$ & $0.245 \pm 0.051$ \\
\hline 3 & Ethanol group & $62.35 \pm 2.37^{*}$ & $56.24 \pm 2.14^{*}$ & $44.26 \pm 1.45^{\star}$ & $0.691 \pm 0.596$ \\
\hline 4 & $\mathrm{CCl}_{4}+$ olive oil & $162.35 \pm 2.37$ & $152.35 \pm 0.39$ & $142.35 \pm 1.34$ & $1.289 \pm 0.19$ \\
\hline 5 & Silymarin + olive oil & $89.31 \pm 1.32$ & $84.12 \pm 1.25$ & $72.17 \pm 0.38$ & $0.571 \pm 0.22$ \\
\hline 6 & Pollen extract at $100 \mathrm{mg} / \mathrm{kg}$ & $68.31 \pm 1.27^{*}$ & $69.23 \pm 2.14^{*}$ & $67.26 \pm 1.45^{*}$ & $0.169 \pm 0.33$ \\
\hline 7 & Pollen extract at $200 \mathrm{mg} / \mathrm{kg}$ & $61.38 \pm 2.76$ & $58.34 \pm 1.32$ & $61.24 \pm 2.35$ & $0.186 \pm 0.02$ \\
\hline 8 & Pollen extract at $300 \mathrm{mg} / \mathrm{kg}$ & $57.48 \pm 1.53$ & $61.54 \pm 0.78$ & $62.35 \pm 2.57$ & $0.192 \pm 0.01$ \\
\hline
\end{tabular}

*Significant $(p<0.05)$ values vs control/normal and expressed as mean $\pm S D, n=5$

ALT: Alanine aminotransferase, AST: Aspartate aminotransferase, ALP: Alkaline phosphatase, SD: Standard deviation, $\mathrm{CCl}_{4}$ : $\mathrm{Carbon}_{\text {tetrachloride }}$

Table 3. Effects of red pine pollen extract on blood cell parameters in mice

\begin{tabular}{lllll} 
Group & Treatment & RBCs $\left(10^{6} / \mathrm{mm}^{3}\right)$ & WBCs $\left(10^{3} / \mathrm{mm}^{3}\right)$ & Platelets $\left(10^{3} / \mathrm{mm}^{3}\right)$ \\
\hline 1 & Normal (vehicle) & $4.65 \pm 0.31$ & $5.38 \pm 1.34$ & $259.24 \pm 1.36$ \\
\hline 2 & Olive oil group & $4.87 \pm 0.51$ & $6.24 \pm 0.33$ & $245.23 \pm 1.26$ \\
\hline 3 & Ethanol group & $3.25 \pm 0.37$ & $3.64 \pm 0.14$ & $234.26 \pm 1.45$ \\
\hline 4 & $\mathrm{CCl}_{4}+$ olive oil & $1.25 \pm 0.37$ & $1.55 \pm 0.39$ & $132.35 \pm 1.54$ \\
\hline 5 & Silymarin + olive oil & $3.91 \pm 0.32$ & $4.42 \pm 0.25$ & $242.15 \pm 1.38$ \\
\hline 6 & Pollen extract at $100 \mathrm{mg} / \mathrm{kg}$ & $4.81 \pm 0.27^{*}$ & $5.93 \pm 0.14$ & $243.56 \pm 2.15$ \\
\hline 7 & Pollen extract at $200 \mathrm{mg} / \mathrm{kg}$ & $4.68 \pm 0.76$ & $4.84 \pm 0.32$ & $241.22 \pm 1.37$ \\
\hline 8 & Pollen extract at $300 \mathrm{mg} / \mathrm{kg}$ & $4.98 \pm 0.53$ & $4.91 \pm 0.35$ & $248.12 \pm 0.58$ \\
\hline
\end{tabular}

*Significant $(p<0.05)$ values vs. control/normal and expressed as mean $\pm S D, n=5$

RBC: Red blood cell, WBC: White blood cell, SD: Standard deviation, $\mathrm{CCl}_{4}$ : Carbon tetrachloride 
hepatoprotective effect via normalization of AST, ALT, and ALP levels as well as hypolipidemic and hypocholesterolemic activity in testosterone-androgenized rats. ${ }^{36}$ The same extract was also shown to have a protective effect in a paracetamolinduced hepatotoxicity model in mice along with hypolipidemic effect. $^{27}$

Bee pollen from China was previously demonstrated effective in decreasing the amount of lipofuscin (fine yellow-brown pigment granules composed of lipid-containing residues of lysosomal digestion) in cardiac muscle, liver, and brain as well as adrenal gland cells in $\mathrm{NIH}$ mice. ${ }^{37}$ Additionally, bee pollen extract with a rich polyphenol content from Poland was tested for its antiatherogenic effect in apolipoprotein E-knockout mice at two doses of 0.1 and $1 \mathrm{~g} / \mathrm{kg}$ body weight (b.w.) for 16 weeks. ${ }^{32}$ The extract led to a decrease in triglyceride and LDL cholesterol levels and displayed complete protection of the coronary arteries at $1 \mathrm{~g} / \mathrm{kg}$ b.w. The effect was speculated to correlate with the polyphenol content of the pollen extract, which was supported by histopathological data on the cardiac vessels. In another study, a strong hepatoprotective effect of a pollen ethanol (70\%) extract prepared from Phoenix canariensis hort. ex Chabaud as one of the palm species was shown in adult male Wistar albino rats. ${ }^{38}$ The pollen extract was found to contain isorhamnetin-3O-rutinoside and rutin as the phenolic compounds, which were concluded to contribute to its hepatoprotective effect. Yildiz et al. ${ }^{29}$ studied the hepatoprotective effect of chestnut bee pollens collected from the western Black Sea region of Turkey at doses of 200 and $400 \mathrm{mg} / \mathrm{kg} /$ day through $\mathrm{CCl}_{4}$-induced liver damage in Sprague-Dawley rats. Particularly, bee pollen extract led to a significant decrease in AST and ALT levels at a dose of $400 \mathrm{mg} /$ $\mathrm{kg}$, whereas silybinin administered at a dose of $50 \mathrm{mg} / \mathrm{kg}$ in rats revealed a better hepatoprotective effect as compared with that of bee pollen extract at $200 \mathrm{mg} / \mathrm{kg}$. Phytochemical analysis of chestnut pollen pointed to the presence of total phenolic compounds (28.87 mg GA equivalent/g), total flavonoids ( $8.07 \mathrm{mg}$ quercetin equivalent/g), total anthocyanins $(92.71 \mathrm{mg}$ cyanidin-3-glucose equivalent $/ \mathrm{kg}$ ), and total carotenoids (29 mg $\beta$-carotene equivalent $/ 100 \mathrm{~g}$ ). Since the antioxidant activity of the extract in that study was also consistent with its hepatoprotective effect, the phenolic compounds analyzed in the extract were considered to contribute to its antioxidant and hepatoprotective effects. Similarly, the pollen extract of Schisandra chinensis of Chinese origin was reported to exert strong antioxidant and hepatoprotective effects against hepatotoxicity induced by $\mathrm{CCl}_{4}$, which is consistent with our data. ${ }^{28}$ Recently, Taishan Pinus massoniana pollen extract was shown to exert marked hepatoprotection in $\mathrm{CCl}_{4}$-induced oxidative stress in the liver of rats tested at doses of 100, 200, and $400 \mathrm{mg} / \mathrm{kg}$ b.w., where AST, ALT, ALP, lactic dehydrogenase (LDH), malondialdehyde (MDA), superoxide dismutase (SOD), and glutathione peroxidase levels were significantly reduced. ${ }^{31}$ The strong hepatoprotective action of this pollen extract was concluded to be a result of its polysaccharide content, which was described as an acidic heteropolysaccharide with glucose

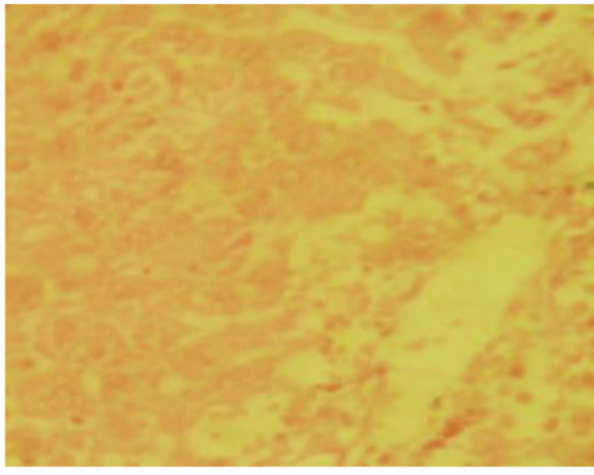

(a)

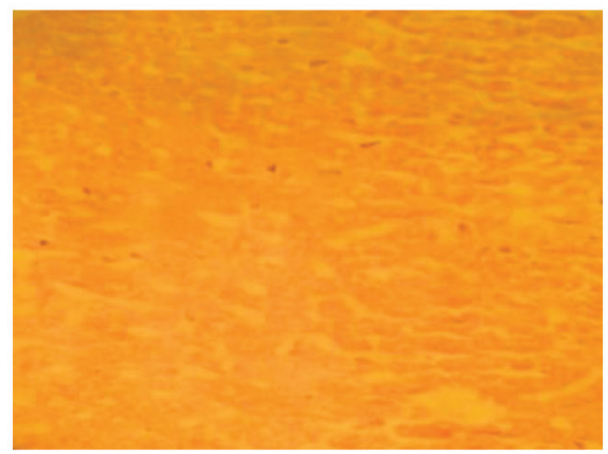

(c)

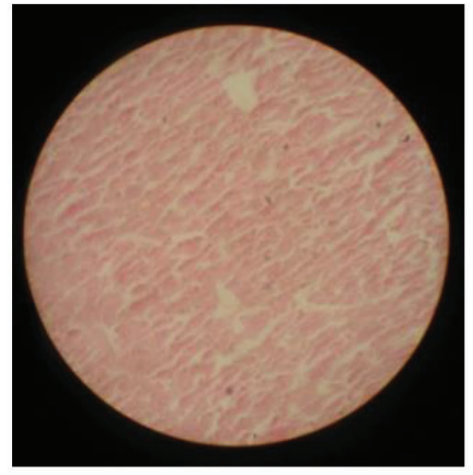

(b)

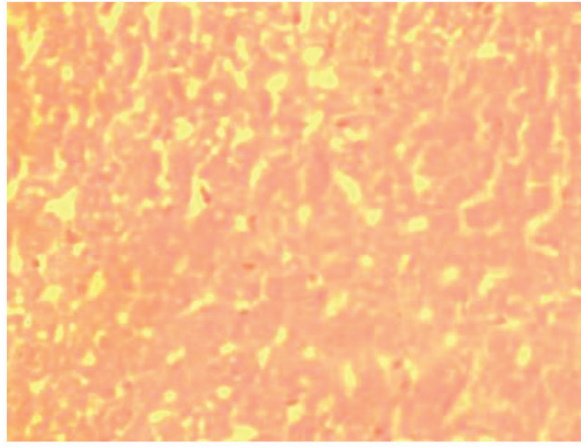

(d)

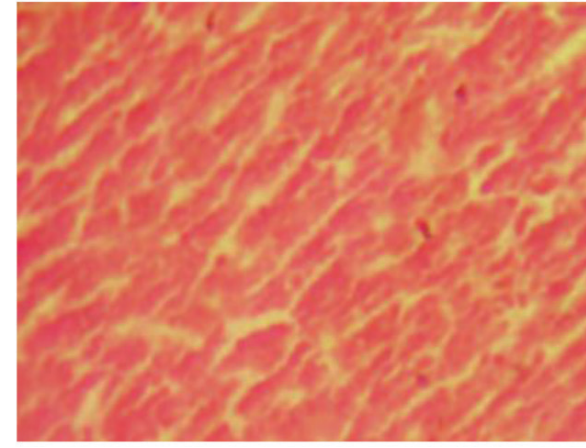

(e)

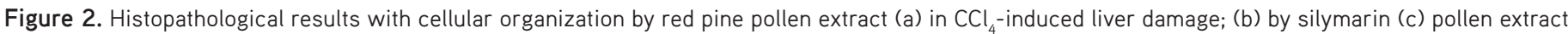
at $100 \mathrm{mg} / \mathrm{kg}$; (d) pollen extract at $200 \mathrm{mg} / \mathrm{kg}$; (e) pollen extract at $300 \mathrm{mg} / \mathrm{kg}$

$\mathrm{CCl}_{4}$ : Carbon tetrachloride 
and arabinose as the key constituent monosaccharides. On the other hand, Rzepecka-Stojko et al. ${ }^{32}$ mentioned a positive correlation between polyphenols present in bee pollen and its hepatoprotective and other biological activities.

In another study on honeybee products including chestnut honey, pollen, propolis, and royal jelly, their hepatoprotective activity was investigated using a $\mathrm{CCl}_{4}$-induced model in rats. ${ }^{39}$ Recovery of hepatotoxicity was observed by measuring AST and ALT levels as well as oxidative stress parameters such as MDA, SOD, and catalase (CAT). The use of bee pollen due to its discernible bioactivities was also suggested to be beneficial not only for human health but also for animal health (up to $20 \mathrm{~g} / \mathrm{kg}$ diet) for production and health patterns of livestock. ${ }^{40}$

On the other hand, VA was detected as the major phenolic compound in the extract along with some other phenolic acids. In fact, VA was reported to have a strong hepatoprotective activity in a number of plant or mushroom extracts. ${ }^{41}$ For instance, VA and SA were reported to be the active constituents in edible mushroom Lentinula edodes (shiitake) in concanavalin A-induced liver injury in mice. ${ }^{42}$ In another study, L. edodes, rich in VA and SA, was shown to exert strong hepatoprotection in mice with acute and chronic liver injury induced by $\mathrm{CCl}_{4}$, which is in good agreement with our findings. ${ }^{43}$ The phenolic composition of a Taiwanese mushroom species, Xylaria nigripes, with a high amount of epicatechin, catechin, and p-COU, was interpreted to be related to its activity against in vivo $\mathrm{CCl}_{4}$-induced hepatotoxicity by Song et al. ${ }^{44}$

Consistently, the leaf methanol extract of Capparis spinosa of Tunusian origin, found to contain rutin, resveratrol, coumarin, epicatechin, luteolin, catechin, kaempferol, VA, and GA, led to a notable decrease in serum ALT, AST, and $\mathrm{LDH}$ levels in $\mathrm{CCl}_{4}{ }_{-}^{-}$ induced acute liver damage, as well as in the amount of hepatic MDA formation, whereas it raised the activities of SOD, CAT, and GPx, and repaired injury that occurred in the liver..$^{45}$ In a similar study, a strong hepatoprotective effect was observed with the hot aqueous extract prepared from the leaves of Asparagus albus in male Wistar rats by Serairi-Beji et al. ${ }^{46}$, where some phenolic acids, e.g., GA, VA, and 3,4-dimethoxybenzoic acid, along with several flavonoids, e.g., catechin, rutin, and quercetin, were identified through HPLC. The authors commented that the hepatoprotective effect of the extract was correlated with its polyphenolic content. A remarkable in vivo hepatoprotection was caused by Artocarpus lakoocha fruits which contain chromatotropic, gallic, vanillic, cinnamic, and FAs as well as quercetin and kaempferol, which is consistent with the findings of our study. ${ }^{47}$ A in vivo study parallel to ours was conducted on the hepatoprotective effect induced by thioacetamide of the ethanol extract of Prunus amygdalus stem and leaves from Egypt. ${ }^{48}$ Analysis of the extract using LC-DAD-ESI-MS in negative ion mode indicated the presence of a number of phenolics, including VA and homovanillic acid, which were correlated to hepatoprotection by the plant. Actually, all these previous studies have underlined a considerable contribution of VA to the hepatoprotective activity of a number of plants, which may also lead us to propose that VA might be the major compound responsible for the hepatoprotective effect of red pine pollen extract.

\section{CONCLUSION}

Red pine pollen extract exhibited remarkable and dosedependent hepatoprotection against $\mathrm{CCl}_{4}$-induced liver damage in mice. Phenolic compounds, VA in particular, present in the pollen extract could be responsible for its notable hepatoprotective effect. We conclude that red pine pollen extract has the potential to serve as a promising hepatoprotective agent.

Conflicts of interest: No conflict of interest was declared by the authors. The authors alone are responsible for the content and writing of the paper.

\section{REFERENCES}

1. Kmiec Z. Cooperation of liver cells in health and disease. Adv Anat Embryol Cell Biol. 2001;161:III-XIII, 1-151.

2. Ramadori G, Moriconi F, Malik I, Dudas J. Physiology and pathophysiology of liver inflammation, damage and repair. J Physiol Pharmacol. 2008;59(Suppl 1):107-117.

3. Li B, Shen YH, He YR, Zhang WD. Chemical constituents and biological activities of Pinus species. Chem Biodivers. 2013;10:2133-2160.

4. Kandemir A, Mataracı T. Pinus L. In: Güner A, Kandemir A, Menemen Y, Yıldırım H, Aslan S, Ekși G, Güner I, Çimen AÖ, eds. Resimli Türkiye Florası (Illustrated Flora of Turkey) 2. İstanbul; ANG Vakfı Nezahat Gökyiğit Botanik Bahçesi Yayınları; 2018:325.

5. Fady B, Semerci H, Vendramin GG EUFORGEN Technical Guidelines for genetic conservation and use for Aleppo pine (Pinus halepensis) and Brutia pine (Pinus brutia). Bioversity International, 2003.

6. Yeşilada E, Honda G, Sezik E, Tabata M, Goto K, Ikeshiro Y. Traditional medicine in Turkey IV. Folk medicine in the Mediterranean subdivision. J Ethnopharmacol. 1993;39:31-38.

7. Polat R, Satil F. An ethnobotanical survey of medicinal plants in Edremit Gulf (Balikesir-Turkey). J Ethnopharmacol. 2012;139:626-641.

8. Sargin SA, Akcicek E, Selvi S. An ethnobotanical study of medicinal plants used by the local people of Alasehir (Manisa) in Turkey. J Ethnopharmacol. 2013;150:860-874.

9. Kizilarslan C, Sevgi E. Ethnobotanical uses of genus Pinus L. (Pinaceae) in Turkey. Indian J Tradit Know. 2013;12:209-220.

10. Martin PS, Sharrock FW. Pollen analysis of prehistoric human feces: a new approach to ethnobotany. Am Antiq. 1964;30:168-180.

11. Linskens HF, Jorde W. Pollen as food and medicine - a review. Econ Bot. 1997;51:78-86.

12. de Miranda Chaves SA, Reinhard KJ. Paleopharmacology and pollen: theory, method, and application. Mem Inst Oswaldo Cruz. 2003;98(Suppl 1):207-211.

13. Delahunty JL. The ethnobotanical history and holocene extent of yew (Taxus baccata L.) on the Irish landscape. J Ethnobiol. 2007;27:204218.

14. Dexter DF, Martin K, Travis L. Prehistoric plant use at beaver creek rock shelter, Southwestern Montana, USA. Ethnobot Res Appl. 2014:12:355384. 
15. Martkoplishvili I, Kvavadze E. Some popular medicinal plants and diseases of the Upper Palaeolithic in Western Georgia. J Ethnopharmacol. 2015;166:42-52.

16. Thakur M, Asrani RK, Thakur S, Sharma PK, Patil RD, Lal B, Parkash O. Observations on traditional usage of ethnomedicinal plants in humans and animals of Kangra and Chamba districts of Himachal Pradesh in North-Western Himalaya, India. J Ethnopharmacol. 2016;191:280-300.

17. Choi EM. Antinociceptive and antiinflammatory activities of pine (Pinus densiflora) pollen extract. Phytother Res. 2007;21:471-475.

18. Xiaoyan H, Xueyuan S, Zhiyang Y. Effective components and pharmacological function of pine pollen. J Northeast Forestry Univ. 2007;9:030.

19. Kivrak I, Kivrak S, Harmandar M, Cetintas Y. Phenolic compounds of Pinus brutia Ten.: Chemical investigation and quantitative analysis using an Ultra-Performance Liquid Chromatography Tandem Mass Spectrometry with Electrospray lonization source. Rec Nat Prod. 2013;7:313-319.

20. Sensoz S. Slow pyrolysis of wood barks from Pinus brutia Ten. and product compositions. Bioresour Technol. 2003;89:307-311.

21. Guri A, Kefalas P, Roussis V. Antioxidant potential of six pine species. Phytother Res. 2006;20:263-266.

22. Yesil-Celiktas O, Otto F, Gruener S, Parlar H. Determination of extractability of pine bark using supercritical $\mathrm{CO}_{2}$ extraction and different solvents: Optimization and prediction. J Agric Food Chem. 2009;57:341347.

23. Kilic A, Hafizoglu H, Tumen I, Donmez IE, Sivrikaya H, Hemming J. Phenolic extractives of cones and berries from Turkish coniferous species. Eur J Wood Wood Prod. 2011;69:63-66.

24. Cretu E, Karonen M, Salminen JP, Mircea C, Trifan A, Charalambous C, Constantinou Al, Miron A. In vitro study on the antioxidant activity of a polyphenol-rich extract from Pinus brutia bark and its fractions. J Med Food. 2013;16:984-991.

25. Cetin EO, Yesil-Celiktas O, Cavusoglu T, Demirel-Sezer E, Akdemir $O$, Uyanikgil Y. Incision wound healing activity of pine bark extract containing topical formulations: a study with histopathological and biochemical analyses in albino rats. Pharmazie. 2013;68:75-80.

26. Yener HO, Saygideger SD, Sarikurkcu C, Yumrutas O. Evaluation of antioxidant activities of essential oils and methanol extracts of Pinus species. J Essent Oil Bear PI. 2014;17:295-302.

27. Czarnecki R, Librowski T, Polanski M. [Hepatoprotective effect of flower pollen lipid extract in paracetamol-induced hepatotoxicity in mice]. Folia Med Cracov. 1997;38:53-61.

28. Cheng N, Ren N, Gao H, Lei X, Zheng J, Cao W. Antioxidant and hepatoprotective effects of Schisandra chinensis pollen extract on $\mathrm{CCl}_{4}-$ induced acute liver damage in mice. Food Chem Toxicol. 2013;55:234240.

29. Yildiz O, Can Z, Saral O, Yulug E, Ozturk F, Aliyazicioglu R, Canpolat S, Kolayli S. Hepatoprotective potential of chestnut bee pollen on carbon tetrachloride-induced hepatic damages in rats. Evid Based Complement Alternat Med. 2013;2013:461478.

30. Peng D, Sun L, Pang J, Xu X, Du X, Wang X, Ge M. The separation and cytological screening of hepatoprotective components in rape bee pollen. J Chin Inst Food Sci Technol. 2014;14:100-105.

31. Zhou C, Yin S, Yu Z, Feng Y, Wei K, Ma W, Ge L, Yan Z, Zhu R. Preliminary characterization, antioxidant and hepatoprotective activities of polysaccharides from Taishan Pinus massoniana pollen. Molecules. 2018;23:281.

32. Rzepecka-Stojko A, Kabala-Dzik A, Kubina R, Jasik K, Kajor M, Wrzesniok $D$, Stojko J. Protective effect of polyphenol-rich extract from bee pollen in a high-fat diet. Molecules. 2018;23:805.

33. Ozturk N, Tuncel M, Tuncel NB. Determination of phenolic acids by a modified HPLC: Its application to various plant materials. J Liq Chromatogr Rel Technol. 2007;30:587-596.

34. OECD. OECD guideline for testing of chemicals. Acute oral toxicity Acute toxic class method 2001. Available from: https://ntp.niehs.nih.gov/ iccvam/suppdocs/feddocs/oecd/oecd_gl423.pdf

35. Bierman EL. Dietary carbohydrates and hyperlipemic states in man. Ann Nutr Metab. 1975;18:108-114.

36. Polanski M, Czarnecki R, Woron J. The hepatoprotective and hyoplipidemic effect of flower pollen lipid extract in androgenized rats. Folia Med Cracov. 1996;37:89-95.

37. Liu X, Li L. Morphological observation of effect of bee pollen on intercellura lipofuscin in $\mathrm{NIH}$ mice. Zhongguo Zhong Yao Za Zhi. 1990;15:561-563, 578.

38. Hifnawy MS, Mahrous AM, Sleem AA, Ashour RM. Comparative chemical and biological studies of leaves and pollens of Phoenix canariensis hort. ex Chabaud. Future Med Chem. 2017;9:871-880.

39. Saral O, Yildiz O, Aliyazicioglu R, Yulug E, Canpolat S, Ozturk F, Kolayli S. Apitherapy products enhance the recovery of $\mathrm{CCl}_{4}$-induced hepatic damages in rats. Turk J Med Sci. 2016;46:194-202.

40. Abdelnour SA, Abd El-Hack ME, Alagawany M, Farag MR, Elnesr SS. Beneficial impacts of bee pollen in animal production, reproduction and health. J Anim Physiol Anim Nutr (Berl). 2019;103:477-484.

41. Almeida IV, Cavalcante FM, Vicentini VE. Different responses of vanillic acid, a phenolic compound, in HTC cells: cytotoxicity, antiproliferative activity, and protection from DNA-induced damage. Genet Mol Res. 2016;15:gmr15049388.

42. Itoh A, Isoda K, Kondoh M, Kawase M, Kobayashi M, Tamesada M, Yagi K. Hepatoprotective effect of syringic acid and vanillic acid on concanavalin a-induced liver injury. Biol Pharm Bull. 2009;32:1215-1219.

43. Yagi K. [Liver protective effect of Lentinula edodes mycelia(LEM)]. Gan To Kagaku Ryoho. 2012;39:1099-1102.

44. Song A, Ko HJ, Lai MN, Ng LT. Protective effects of Wu-Ling-Shen (Xylaria nigripes) on carbon tetrachloride-induced hepatotoxicity in mice. Immunopharmacol Immunotoxicol. 2011;33:454-460.

45. Tlili N, Feriani A, Saadoui E, Nasri N, Khaldi A. Capparis spinosa leaves extract: Source of bioantioxidants with nephroprotective and hepatoprotective effects. Biomed Pharmacother. 2017;87:171-179.

46. Serairi-Beji R, Wannes WA, Hamdi A, Tej R, Ksouri R, Saidani-Tounsi M, Lachaal M, Karray-Bouraoui N. Antioxidant and hepatoprotective effects of Asparagus albus leaves in carbon tetrachloride-induced liver injury rats. J Food Biochem. 2018;42:e12433.

47. Saleem M, Asif A, Akhtar MF, Saleem A. Hepatoprotective potential and chemical characterization of Artocarpus lakoocha fruit extract. Bangl J Pharmacol. 2018;13:90-97.

48. Moqbel H, El Hawary SSE, Sokkar NM, El-Naggar EB, Boghdady N, El Halawany AM. HPLC-ESI-MS/MS characterization of phenolics in Prunus amygdalus, cultivar "umm alfahm" and its antioxidant and hepatoprotective activity. J Food Meas Charact. 2018;12:808-819. 